\author{
Kamil Biały \\ (Uniwersytet Szczeciński)
}

\title{
Konstantyn Dalassen w Zarysie historii Jana Skylitzesa
}

\author{
Constantine Dalassenos in John Skylitzes' Synopsis Historion
}

\section{STRESZCZENIE:}

Jan Skylitzes, autor Zarysu historii, to kronikarz, który przejawiał niezwykłe zainteresowanie genealogią wielkich rodzin arystokratycznych, a także losami jej przedstawicieli. Jedną z takich postaci był Konstantyn Dalassen. Dziejopis ukazał jego losy w niezwykły sposób, odbiegający od innych współczesnych mu narracji. Materiał źródłowy zdaje się wskazywać, że Skylitzes wykorzystał przy tym niezachowane źródło związane z Dalassenem. Historyk był szczególnie zainteresowany losami Dalassena, gdyż to ważna postać na dworze cesarza Aleksego I Komnena i jego matki Anny Dalasseny. Ukazał losy Dalassena w przychylnym dla niego świetle jako pierwotnego następcę Konstantyna VIII i ofiarę represji ze strony nisko urodzonych Paflagończyków. Skylitzes chciał w ten sposób wykazać związki łączące Dalassenów z dynastią macedońską a tym samym wzmocnić ideologiczne podstawy panowania Aleksego I Komnena.

Słowa kluczowe: Jan Skylitzes, Zarys historii, Konstantyn Dalassen, Anna Dalassena, Aleksy I Komnen, Bizancjum

Jedną z głównych cech Zarysu historii Jana Skylitzesa jest szczególne zainteresowanie autora genealogią wielkich rodzin arystokratycznych $\mathrm{i}$ ich rolą w dziejach cesarstwa bizantyńskiego ${ }^{1}$. Preferencje Skylitzesa są konsekwencją przyjętych przez niego założeń i celów, jakim przyświecało powstanie Zarysu historii, a te $\mathrm{z}$ kolei rezultatem przemian $\mathrm{w}$ kulturze

${ }^{1}$ C. Holmes, Basil II and the Governance of Empire (976-1025), Oxford 2005, s. 198-202; Skylitzes starał się nawet uzupełniać informacje genealogiczne wykorzystanych źródeł, gdy były one jego zdaniem niewystarczające i niejednokrotnie popełniał przy tym błąd, por. D. I. Polemis, Some cases of erroneous identification in the chronicle of Skylitzes, "Byzantinoslavica” („ByzSlav”) 1965, t. 26, s. 74-75; na temat Skylitzesa zob. W. Seibt, Johannes Skylitzes: Zur Person des Chronisten, "Jahrbuch der Österreichischen Byzantinistik” 1976, t. 25, s. 81-85. 
bizantyńskiej, szczególnie literackiej, które zaszły za panowania dynastii macedońskiej i w drugiej połowie XI $\mathrm{w}^{2}$. Przedstawiciele bizantyńskiej arystokracji znajdują się w centrum zainteresowania Skylitzesa i pełnią istotną rolę w narracji jego dzieła. Dobrze zbadane w tym zakresie są chociażby postacie Jerzego Maniakesa i Katakalona Kekaumena. Osiągnięcia na tym polu zawdzięczamy Jonathanowi Shepardowi, który wykazał, że Skylitzes korzystał z szeregu niezachowanych do dziś źródeł narracyjnych szczególnie związanych z Maniakesem czy Kekaumenem, tj. biografii, autobiografii lub dzienników wojskowych, co zdecydowanie wpłynęło na ostateczny kształt jego tekstu3 ${ }^{3}$.

Postacią którą Skylitzes traktuje w szczególny sposób, jest Konstantyn Dalassen. Podobnie jak Kekaumen, przedstawiony został w zdecydowanie pozytywnym świetle, lecz nie jako wielki wódz, a ofiara represji ze strony Jana Orfanotrofosa i Michała IV Paflagończyka. Wydaje się, że podobnie jak w przypadku omówionych wcześniej wodzów, Skylitzes do opisu losów Dalassena wykorzystał dwa niezachowane i niewymienione przez niego w prooimionie do Zarysu historii źródła, z których jedno było pozytywnie ustosunkowane do Konstantyna Dalassena i jego rodziny, drugie zaś było co najmniej obojętne. Celem niniejszego artykułu jest ukazanie roli, jaką pełnił Konstantyn Dalassen w narracji Jana Skylitzesa i czym była ona uwarunkowana.

Konstantyn Dalassen po raz pierwszy na kartach Zarysu historii pojawia się w rozdziale poświęconym panowaniu Konstantyna VIII. Umierający władca miał, zdaniem Skylitzesa, pierwotnie wybrać na swego następcę nie Romana Argyrosa, lecz Konstantyna Dalassena. Cesarz wy-

${ }^{2} \mathrm{Na}$ temat historiografii bizantyńskiej omawianego okresu zob. np.: F. Hirsch, Byzantinische Studies, Leipzig 1876; K. Krumbacher, Geschichte der byzantinischen Litteratur von Justinian bis zum Ende des oströmischen Reiches, 527-1453, München 1891, s. 33-154; J. P. Alexander, Secular biography at Byzantium, "Speculum” 1940, t. 15, nr 2, s. 194-209; R. J. H. Jenkins, The Classical Background of the Scriptores Post Theophanem, "Dumbarton Oaks Papers" (DOP) 1854, t. 8, s. 13-30; H. G. Beck, Die hochsprachliche profane Literatur der Byzantiner, München 1978, s. 243-504; J. N. Ljubarskij, Man in Byzantine Historiography from John Malalas to Michael Psellos, DOP 1992, t. 46, s. 177-186; A. Kazhdan, The History of Byzantine Literature (800-1000), Athens 2006, s. 7-42, 133-184, 273-294; A. Markopoulos, From narrative historiography to historical biography. New trends in Byzantine historical writing in the 10th-11th centuries, „Byzantinische Zeitschrift” 2006, t. 102, nr 2, s. 696-715.

${ }^{3} \mathrm{~J}$. Shepard, Byzantium's Last Sicilian Expedition: Skylitzes' Testimony, "Rivista Studi Bizantini e Noellenici" 1977-1979, t. 14-16, s. 154; badacz stwierdza, że błędnie przedstawioną z punktu chronologii ostatnią wyprawę sycylijską Skylitzes spisał opierając się na trzech odmiennych źródła, z których jedno, nazwane przez niego źródłem „B”, było pamfletem na cześć Maniakesa; na temat Kekaumena zob. idem, A suspected source of Scylitzes' Synopsis Historion: the great Catacalon Cecaumenus, „Byzantine and Modern Greek Studies” 1992, t. 16, s. 178, zdaniem badacza Skylitzes wykorzystywał tzw. źródło „C', biografię bądź autobiografię Kekaumena. 
słał do Dalassena (przebywającego w swym domu w temie Armeniakon) eunucha Ergodotesa, aby ten sprowadził go do pałacu. Plan cesarza porzucono jednak po interwencji Symeona. Posłał on do Dalassena drugiego posłańca z nowymi instrukcjami, nakazującymi mu pozostanie w swej posiadłości i zignorowanie poleceń Ergodotesa ${ }^{4}$. Natomiast cesarzowi Symeon podsunął kandydaturę swego przyjaciela Romana Argyrosa. Przedstawiono mu alternatywę: porzucenie żony i małżeństwo z cesarską córką albo utratę wzroku ${ }^{5}$. Zdaniem Skylitzesa Roman Argyros nie wiedział, co ma uczynić, dopóki jego żona dobrowolnie nie porzuciła małżeństwa i nie wstąpiła do klasztoru6.

W rozdziale poświęconym panowaniu Romana III Argyrosa Dalassen pojawia się tylko raz, jako uczestnik nieudanej wyprawy na Aleppo. Po klęsce tagmy Ekskubitorów pod wodzą Leona Choirosfaktesa Dalassen został wysłany, aby uratować sytuację7, gdyż Arabowie odcięli obóz cesarski pod Azaz od źródeł zaopatrzenia. Poniósł jednak klęskę po krótkim starciu z wrogiem i wycofał się w nieładzie, doprowadzając do chaosu w obozie cesarskim. Roman III Argyros zdecydował o odwrocie do Antiochii, ponosząc przy tym, według Skylitzesa, duże straty ${ }^{8}$.

Chociaż autor Zarysu historii milczy na temat stosunku Dalassena do panowania Argyrosa, to jednak w przypadku akcesji Michała IV otwarcie wyraża swą dezaprobatę. Zdaniem Skylitzesa jako jedyny nie przyjął wyboru Paflagończyka z zadowoleniem. Nastawienie Dalassena nie spodobało się bratu cesarza, Janowi Orfanotrofosowi, który zastanawiał się, w jaki sposób skłonić dumnego arystokratę do posłuszeństwa. Posłał do niego Ergodotesa (tego samego, który zaniósł mu wcześniej wiadomość

${ }^{4}$ Skylitzes, Synopsis Historiarum, red. I. Thurn, Corpus Fontium Historiae Byzantinae (CFHB), 5, Berlin-New York 1973, 373.15-374.26.

${ }^{5}$ Jest to wersja, którą przytacza Skylitzes, Synopsis, 374.26-29; natomiast Psellos, Michele Psello Imperatori di Bisanzio (Cronografia), red. S. Impellizzeri, tłum. S. Ronchey, Roma 1984, II, 10, podaje, że gniew Konstantyna wobec Romana był jedynie udawany, a miał na celu podstępne skłonienie jego żony do uległości.

${ }^{6}$ Skylitzes, Synopsis, 374.29-32, podkreśla dobrowolność czynu żony Argyrosa.

${ }^{7}$ Wydaje się, że Dalassen był właściwą osobą do tego zadania ze względu na swe doświadczenie w sprawach syryjskich i zważywszy na fakt, że sprawował wcześniej funkcje katepana Antiochii, Histoire de Yahya ibn Sa'id d'Antioche, red. I. Kratchkovsky, F. Micheau, G. Troupeau, Patrologia Orientalis, 47.4, Turnhout 1997, 476; por. Catalogue of Byzantine Seals at Dumbarton Oaks and in the Fogg Museum of Art, 5, red. E. McGeer, J. Nesbitt, N. Oikonomides, Washington 2005, 9.1, jednakże identyfikacja pieczęci z Konstantynem Dalassenem jest niepewna; J.-C. Cheynet, J.-F. Vannier, Études prosopographiques, Paris 1986, s. 80.

${ }^{8}$ Skylitzes, Synopsis, 380.8-381.24; zdaniem Psellosa (Cronografia, III 9-10) potyczka nie trwała długo, gdyż wojsko bizantyńskie szybko wpadło w panikę i zaczęło uciekać, a muzułmanie stali w osłupieniu, nie rozumiejąc, dlaczego wróg wycofywał się w nieładzie i bez żadnego powodu. 
od Konstantyna VIII), aby sprowadził go do pałacu, jednakże nie udało mu się przekonać nieufnego Dalassena do wyjazdu. Wtedy wysłano do niego Konstantyna Fagitesa, enucha z Paflagonii i zausznika cesarza, który przywiózł mu relikwię Prawdziwego Krzyża, mandylion z Edessy, list Chrystusa do króla Abgara i ikonę Matki Boskiej ${ }^{9}$. Dopiero przysięga poświadczona tymi relikwiami przekonała Konstantyna Dalassena do udania się do stolicy. W Konstantynopolu został życzliwie przyjęty przez Michała IV, otrzymał godność prokonsula (anthypatos) ${ }^{10}$ i zamieszkał w posiadłości w dzielnicy ta Kyrou ${ }^{11}$.

Dalassen przebywał w Konstantynopolu kilka miesięcy. Jego pokój z Paflagończykami trwał jednak dopóty, dopóki przebywał w mieście. Skylitzes informuje, że Jan Orfanotrofos sprowadził go ponownie do stolicy i wygnał na wyspę Plateję. Uwięziono również zięcia Dalassena, Konstantyna Dukasa ${ }^{12}$, który protestował przeciwko surowemu potraktowaniu teścia, przypominając o złożonej wcześniej przysiędze. Aresztowano także Goudeliosa, Baianosa i Probatasa, wygnano natomiast protovestiariosa Symeona ${ }^{13}$. Powodem represji wobec Dalassena były zajścia w Antiochii, której mieszkańcy nie chcieli wpuścić do miasta nowego duksa Niketasa, brata cesarza. Odmówili jego przyjęcia, gdyż obawiali się reperkusji za zamordowanie poborcy podatkowego Salibasa. Wpuszczono go, gdy obiecał objąć zbuntowanych mieszkańców amnestia, jednakże nie dotrzymał słowa, mordując stu obywateli i aresztując jedenastu przedstawicieli elity Antiochii, których wysłał w kajdanach do Konstantynopola. Tym, co zdecydowało o banicji Dalassena, był list Niketasa do Jana Orfanotrofosa,

${ }^{9}$ Mandylion z Edessy znalazł się w bizantyńskich rękach w 944 r., gdy mieszkańcy okupowanej Edessy przekazali go Romanowi I Lekapenowi w zamian za zakończenie oblężenia miasta, Skylitzes, Synopsis, 232.69-72; por. homilię Grzegorza Referendariusza poświęconą mandylionowi, a powstałą z okazji jego odzyskania w: A.-M. Dubarle, L'homélie de Grégoire le Référendaire pour la réception de l'image d'Édesse, „Revue des Études Byzantines" (REB) 1997, t. 55, s. 15-29; natomiast odnalezienie w Edessie listu Chrystusa do Abgara Skylitzes (Synopsis, 387.9-11) przypisuje Jerzemu Maniakesowi.

${ }^{10}$ Urząd wywodzący się od dawnego prokonsula, a od IX w. był już tylko średniej rangi godnością usytuowaną między magistrem (magistros) i patrycjuszem (patrikios), N. Oikonomides, Les Listes de Préséance Byzantines Des IXe et Xe Siècles, Paris 1972, s. 287.

${ }^{11}$ Skylitzes, Synopsis, 393.58-394.69, była to dzielnica położona w okolicach kościoła Bożej Rodzicielki między murami konstantyńskim i teodozjańskim. Zamieszkiwali ją możni, a nazwę swą zawdzięczała Cyrusowi, prefektowi Konstantynopola z VI w.: R. Janin, Constantinople byzantin. Développement urbain et répertoire topographique, Paris 1964, s. 216; Konstantynopol - nowy Rzym: miasto i ludzie w okresie wczesnobizantyńskim, red. M. J. Leszka, Warszawa 2011, s. 194.

12 Przyszły cesarz Konstantyn X, córka Dalassena była jego pierwszą żona, a gdy zmarła, ożenił się z Eudokią Makrembolitissa, D. I. Polemis, The Doukai: a Contribution to the Byzantine Prosopography, London 1968, s. 29.

${ }^{13}$ Skylitzes, Synopsis, 396.18-32. 
w którym stwierdził, że opór antiocheńczyków nie był spowodowany morderstwem Salibasa, lecz popularnością Konstantyna Dalassena ${ }^{14}$. Arystokrata długo jednak nie przebywał na Platei, gdyż Jan Orfanotrofos wolał więzić go w Konstantynopolu, gdzie go przeniósł około września 1034 r. $^{15}$

O dalszych losach Konstantyna Dalassena Skylitzes milczy. Wspomina jeszcze o nienazwanym z imienia Dalassenie, którego Jan Orfanotrofos obiecał wysłać na wschód jako doradcę dla swego brata Konstantyna. Mieli za zadanie wspomóc katepana Iberii Jazytesa w odparciu najazdu króla Gruzji Bagrata IV, jednakże Orfanotrofos nie wywiązał się z tej obietnicy ${ }^{16}$. Lakoniczność wzmianki nie pozwala stwierdzić, czy chodziło o Konstantyna, któremu chciano dać w ten sposób szansę na rehabilitację, czy o jakiegoś innego przedstawiciela rodziny. Jest to jednak świadectwem tego, że rozważano pojednanie się z Dalassenami. Fiaskiem owych działań jest ostatnia wzmianka o Dalassenach, dostarczona przez Skylitzesa. W 1039 r. Jan Orfanotrofos skazał na wygnanie braci Konstantyna - Teofylakta i Romana oraz jego bratanka Adriana i innych krewnych ${ }^{17}$. Jest to ostatnia informacja, jakiej udziela Skylitzes na temat Dalassenów.

Stosunek Jana Skylitzesa do Konstantyna Dalassena w Zarysie historii jest niejednoznaczny. Wydaje się, że opierał się na dwóch źródłach, jednym obojętnym wobec arystokraty i drugim zdecydowanie mu przychylnym, będącym prawdopodobnie rodzinną kroniką Dalassena. Na łamach Zarysu historii odnajdujemy łącznie osiem ustępów poświęconych Dalassenowi i jego rodzinie, z czego dwa pierwsze powstały w oparciu o źródło o nastawieniu obojętnym, a sześć pod wpływem hipotetycznej kroniki rodzinnej. Źródło obojętne zostało przez Skylitzesa wykorzystane przy opisie kwestii sukcesji po Konstantynie VIII oraz kampanii Romana III Argyrosa przeciwko Aleppo. Pierwszy z przekazów jest bardzo lakoniczny, Skylitzes w żaden sposób nie ocenia zmiany decyzji odnośnie do sukcesji władzy ani nie przytacza dokładnie okoliczności, w jakich do niej doszło. Stwierdza jedynie, że Symeon, przyjaźnie usposobiony do patrycjusza Romana Argyrosa, w pośpiechu odwołat tę decyzję i wysłał szybko wiadomość od cesarza do Dalassena nakazujaca mu pozostać tam, gdzie będzie, gdy otrzyma to

${ }^{14}$ Ibidem, 395.16-396.18; Konstantyn w ostatnich latach panowania Bazylego II był katepanem Antiochii, zaś jego ojciec Damian i brat Teofylakt zarządzali Antiochią w randze duksa, J.-C. Cheynet, J.-F. Vannier, Études prosopographiques, s. 77, 83; Antiochia była zatem poważnym ośrodkiem wpływów Dalassenów, chociaż Konstantyn cieszył się również ogromną popularnością w stolicy, Psellos, Cronografia, VI 12.

${ }^{15}$ Skylitzes, Synopsis, 396.21.

${ }^{16}$ Ibidem, 402.6-11.

17 Ibidem, 404.50-59. 
pismo ${ }^{18}$. O rozważaniu kandydatury Dalassena do tronu cesarskiego wspomina również Jan Zonaras, który stwierdza, że Konstantyn VIII wybrał na swego następcę Konstantyna Dalassena, lecz zmienił zdanie i posłał po Romana Argyrosa, męża o szlachetnej krwi ${ }^{19}$. Zonaras, inaczej niż Skylitzes, utrzymuje, że cesarz zmienił zdanie bez udziału osób trzecich. Warto przy tym zwrócić uwagę na fakt, że podkreśla szlachetne urodzenie Argyrosa, nie wyrażając przy tym żadnej opinii na temat Dalassena.

Źródła Skylitzesa i Zonarasa są przychylniejsze wobec Argyrosa, jednakże to, z którego korzystał Skylitzes, niewątpliwie związane było z przyszłym cesarzem. Wydaje się, że była nim kronika Demetriusza z Kyzikos, autora wymienionego przez Skylitzesa w prooimionie do Zarysu historii. Dziejopis wspomina o nim w następnym rozdziale jako o przyjacielu Romana Argyrosa z czasów, zanim ten został władcą ${ }^{20}$. Lakoniczność wzmianki na temat okoliczności, w jakich doszło do zmiany decyzji o następstwie tronu, może być wynikiem modyfikacji przekazu Demetriusza z Kyzikos przez Skylitzesa. Dziejopis obiecuje wprawdzie w prooimionie do Zarysu historii, że oczyści swą narrację z takich elementów retorycznych, jak pochwała (enkomion) czy nagana (psogos) ${ }^{21}$, lecz jego dzieło dostarcza wielu przykładów niedotrzymywania tej obietnicy. Hipoteza niniejsza pozostaje zatem jedynie w sferze domysłów.

Zastosowanie przez Skylitzesa przychylnego Argyrosowi źródła odbiło się również na negatywnej ocenie udziału Dalassena w kampanii przeciwko Aleppo. Skylitzes przedstawia wyprawę wojskową na wschodzie w znacznie korzystniejszy dla cesarza sposób, niż czyni to Michał Psellos. Autor Zarysu historii twierdzi, że Roman III był zmuszony do powzięcia kampanii przeciwko Aleppo, gdyż dotychczas podporządkowane miasta syryjskie zrzuciły zwierzchnictwo Bizancjum w wyniku słabości państwa za panowania Konstantyna VIII ${ }^{22}$. Zdaniem Psellosa wyprawa Argyrosa nie miała żadnych realnych podstaw z wyjątkiem żądzy sławy i dlatego

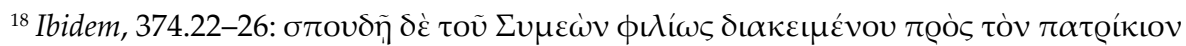

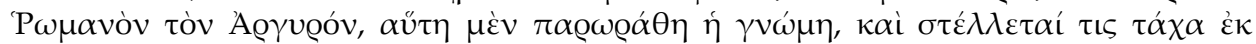

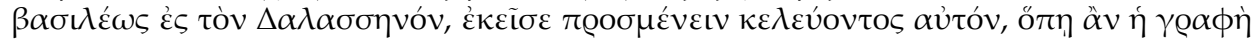
$\kappa \alpha \tau \alpha \lambda \eta \dot{\psi} \eta \tau \alpha \mathrm{L}$.

${ }_{19}$ Zonaras, Epitomae Historiarum, red. M. Pinder, T. Buttner-Wobst, Corpus Scriptorum Historiae Byzantinae (CSHB), Bonn 1897, t. 3, 572.8-18.

${ }^{20}$ Skylitzes, Synopsis, 375.60-61; A. E. Laiou, Imperial Marriages and Their Critics in the Eleventh Century: The Case of Skylitzes, DOP 1992, t. 46, s. 169; dowodzi, że Demetriusz z Kyzikos był autorem źródła przychylnego Argyrosowi, które Skylitzes wykorzystał opisując sprawę sukcesji po Konstantynie VIII i panowanie Romana III Argyrosa, por. W. Treadgold, The Middle Byzantine Historians, Palgrave Macmillan 2013, s. 258-259.

${ }^{21}$ Skylitzes, Synopsis, 4.32-49.

${ }^{22}$ Ibidem, 378.34-51; podobną wersję wydarzeń przedstawił Zonaras, Epitomae, 575.8576.2 . 
też wymyślił fikcyjny powód do wojny z emirem Aleppo ${ }^{23}$. Skylitzes winę za klęskę pod Azaz składa na barki Konstantyna Dalassena, a ostateczny rezultat kampanii przedstawia w korzystnym dla cesarza świetle ${ }^{24}$. Zatem stosunek Skylitzesa do Dalassena w dwóch omówionych ustępach jest co najwyżej obojętny. Wynika to z negatywnego nastawienia Demetriusza z Kyzikos do arystokraty będącego rywalem Argyrosa do tronu cesarskiego. Co jednak istotne, nie wspomina w ogóle o oskarżeniach o zdradę kierowanych do Dalassena ${ }^{25}$, który, jak się wydaje, po kampanii syryjskiej został odsunięty od spraw państwowych ${ }^{26}$.

Diametralna zmiana w narracji Skylitzesa dotyczącej Dalassena zaszła w rozdziale poświęconym panowaniu Michała IV Paflagończyka. Dziejopis przedstawił go jako ofiarę represji cesarza i jego brata Jana Orfanotrofosa. Szczegółowość informacji na temat Dalassena oraz podkreślanie obsesyjnego dążenia Orfanotrofosa do utrzymania go pod kontrolą świadczą o wykorzystaniu przez niego źródła, w którym arystokrata był postacią bardzo istotną jeśli nie centralną. Skylitzes podaje chociażby dokładną datę dzienną zesłania Dalassena na Plateję $e^{27}$. Jest to fakt znaczący, gdyż dziejopis tak dokładnie datuje tylko czas wystąpienia trzęsień ziemi i innych katastrof naturalnych oraz śmierć cesarza Michała IV. Dokładne datowanie katastrof naturalnych czy zjawisk nadprzyrodzonych jest świadectwem wykorzystywania przez Skylitzesa źródła o proweniencji kościelnej, prawdopodobnie autorstwa Jana Lidyjczyka ${ }^{28}$. Wydaje się

${ }^{23}$ Psellos, Cronografia, III, 7.

${ }^{24}$ Sytuacja została uratowana dzięki protospatariosowi Teoktystowi, Skylitzes, Synopsis, 383.86-96.

${ }^{25}$ Mateusz z Edessy, The Chronicle of Matthew of Edessa, Lanham-New York-London 1993, I, 57, jego zdaniem przyczyną klęski Romana III było niezadowolenie armii; por. J. Bonarek, Konstantyn Dalassenos - spadkobierca rzymskich cnót, [w:] Człowiek w antycznym świecie, red. S. Sprawski, Kraków 2012, s. 399.

${ }^{26}$ Świadczy o tym fakt, że w czasie akcesji Michała IV przebywał w swej posiadłości na prowincji, Skylitzes, Synopsis, 393.31-32; Zonaras, Epitomae, 588.3-4.

${ }^{27} 3$ sierpnia 1034 r., Skylitzes, Synopsis, 396.21; cf. Zonaras, Epitomae, 589.6-7, który informuje o zesłaniu Dalassena, lecz go nie datuje. Skylitzes podaje również miesięczną datę sprowadzenia Dalassena do Konstantynopola: sierpień 1034 r. (Synopsis, 396.35-36), jednak odnosi się również do innych wydarzeń i nie można z całą pewnością stwierdzić, że przeniesienie Dalassena odbyło się w tym samym miesiącu. Oprócz tych datuje jeszcze skazanie na wygnanie członków rodziny arystokraty: 1039 (Synopsis, 404.50).

${ }^{28}$ J. Shepard, Last Sicilian Expedition, s. 11-12, uważa, że Skylitzes korzystał z kilku źródeł rocznikarskich; zdaniem A. Laiou, Imperial marriages, s. 171, źródłem była kronika Demetriusza z Kyzikos. Jest to jednak mało prawdopodobne, zważywszy na fakt, że istnieją istotne różnice w stosunku Skylitzesa do patriarchy Aleksego Studyty, wobec którego Demetriusz z Kyzikos był nastawiony niechętnie z powodu różnic natury teologicznej, zob. traktat Demetriusza z Kyzikos dotyczący legalności małżeństw zawieranych przez krewnych do szóstego stopnia pokrewieństwa: G. A. Ralli, M. Potli, $\Sigma v v \tau \alpha \gamma \mu \alpha \tau \omega v \Theta \varepsilon i \omega v$ 
jednak mało prawdopodobne, aby informacje dotyczące Dalassena pochodziły z tego typu źródła. Chociaż oba są zdecydowanie niechętne Michałowi IV i Janowi Orfanotrofosowi, to jednak różnią się co do charakteru krytyki i prezentowanego punktu widzenia.

Zarzuty powstałe pod wpływem źródła, którego autorem prawdopodobnie był Jan Lidyjczyk, dotyczą sfery religijno-moralnej i prezentują kościelny punkt widzenia. Krytyka skupia się głównie na Michale IV i jest konsekwencją dwóch popełnionych przez niego grzechów, dzięki którym utorował sobie drogę do władzy: morderstwa popełnionego na Romanie III i cudzołóstwa z Zoe. Skylitzes nie wyraża żadnych wątpliwości co do przyczyn zgonu cesarza: najpierw był podtruwany przez cesarzową ${ }^{29}$, a następnie uduszony przez popleczników Michała ${ }^{30}$.

W rozdziale poświęconym panowaniu Michała IV odnajdujemy szereg relacji potwierdzających karę za grzechy, jaką Bóg zesłał na Paflagończyka. W jednej z nich Skylitzes donosi, że cesarz został opętany przez demona. Ludzie z nim zwiazani, używając górnolotnych słów, nazywali to choroba wywotujaca szaleństwo ${ }^{31}$. Należy przy tym zwrócić uwagę na fakt, że dziejopis używa identycznego słownictwa na opisanie miłości, jaką żywiła do niego Zoe ${ }^{32}$. O tym, że wizerunek cesarza Michała IV w źródle Skylitzesa uwarunkowany był przez te dwa rodzaje grzechów, świadczy opowieść o słudze biskupa Pergamonu. Miał wizję eunucha nakazującego mu otwarcie trzech szkatul, z których wydostały się różne insekty i potwory, po czym eunuch powiedział (...) to spadło na ciebie $i$ będzie nadal spadać, za zlekceważenie Bożych nakazów oraz za sprofanowanie ce-

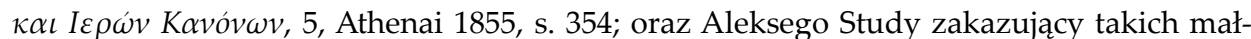
żeństw: ibidem, s. 36-37; niechęć Demetriusza jest widoczna przy okazji opisu postawy patriarchy wobec małżeństwa Zoe z Michałem Paflagończykiem, którego cesarzowa poślubiła bez odbycia żałoby po zmarłym Romanie III. Patriarcha początkowo był zaszokowany, lecz udzielił ślubu po otrzymaniu łapówki od Jana Orfanotrofosa i Zoe (Skylitzes, Synopsis, 390.95-391.8); natomiast w rozdziale poświęconym panowaniu Michała IV Skylitzes jest przychylny patriarsze i opisuje jego zwycięstwo nad Demetriuszem z Kyzikos oraz jego stronnikami, którzy chcieli obalić Aleksego i uczynić patriarchą Jana Orfanotrofosa, (Synopsis, 401.67-80); Skylitzes nie mógł zaczerpnąć tej informacji od Demetriusza z Kyzikos, który raczej nie ukazałby własnej klęski, dlatego wydaje się, że kronikarzem tym był mnich Jan Lidyjczyk, autor jako ostatni wymieniony we wstępie do Zarysu historii, zob. W. Treadgold, The Middle Byzantine Historians, s. 259-260; K. Biały, The Authorship of the Lost Source of John Skylitzes' Synopsis Historion in the Chapter about the Reign of Michael IV, „Eos" 2014, t. 101, nr 2, s. 280-283.

${ }^{29}$ Skylitzes, Synopsis, 390.83 .

${ }^{30}$ Ibidem, 390.94.

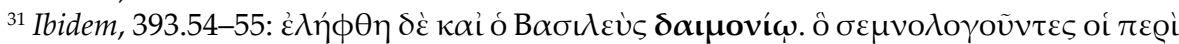

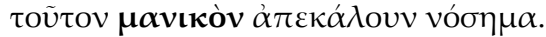

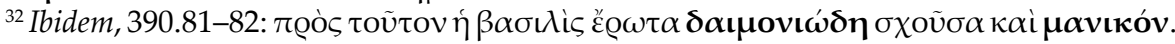


sarza Romana $i$ jego toża matżeńskiego ${ }^{33}$. Skylitzes donosi nawet, że cesarz próbował zadośćuczynić złym uczynkom, lecz były to próby daremne. Skutek przyniosłyby tylko wtedy, gdyby Michał IV porzucił władzę i rozstał się z Zoe. Zamiast tego wciąż żył z cesarzową i opłacał swą dobroczynność z finansów publicznych, sądząc, że uzyska odkupienie za cudze pieniądze ${ }^{34}$. Pomimo nieustającej dobroczynności cesarza (rozdawnictwa pieniędzy dla osób duchownych czy rodziców nowo narodzonych dzieci, które podawał dla chrztu) jego stan wciąż się pogarszał ${ }^{35}$.

Identyczne pochodzenie ma utrzymana $\mathrm{w}$ tym samym tonie krytyka skierowana do Jana Orfanotrofosa, w relacji Skylitzesa rzeczywistego pana Cesarstwa. Nie było już, zdaniem autora Zarysu historii, żadnego rodzaju nieczystego i bezprawnego sposobu postępowania, którego by nie wynalazł dla nędzy i pognębienia podwładnych, a wymienienie ich byłoby iście herkulesową pracą. Wszyscy żyjący pod tyranią Orfanotrofosa szukali pomocy u Boga, który objawiał swój gniew za pomocą przerażających znaków, huraganów, trzęsień ziemi ${ }^{36}$.

Oprócz powyższych zarzutów, którym towarzyszą moralne potępienie i odwołania do boskiego gniewu, pojawiają się również pozbawione tego typu retoryki zarzuty o czysto politycznym charakterze, zawsze powiązane z osobą Konstantyna Dalassena. Po raz pierwszy Skylitzes skorzystał z hipotetycznego źródła związanego z Dalassenami zaraz na początku rozdziału poświęconego panowaniu Michała IV. Wedle relacji autora Zarysu historii Dalassen nie przyjął dobrze wieści o wyborze Paflagończyka: Wszyscy inni ugięli się i dobrym słowem oddali cześć nowemu cesarzowi. Jedynie patrycjusz Konstantyn Dalassen, przebywający wówczas w swej posiadłości, nie przyjął łagodnie tej wiadomości, lecz zniechęcit się do tego, co mówiono i przez to wyraził zdumienie, jak to możliwe, ̇̇e podczas gdy było tak wielu wspaniałych mezów ze znamienitych domów i znacznego urodzenia, pospolity i warty trzy obole człowiek został postawiony wyżej od wszystkich innych i proklamowany jako pan $i$ cesarz $^{37}$. Krytyka Michała IV, wyrażona przez Dalassena, dotyczy zatem

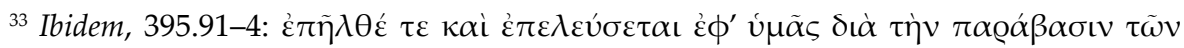

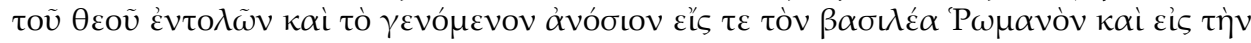

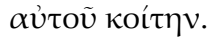

${ }^{34}$ Ibidem, 397.69-398.74.

${ }^{35}$ Ibidem, 405.67-75.

${ }^{36} \mathrm{Ibidem}, 408.55-62$.

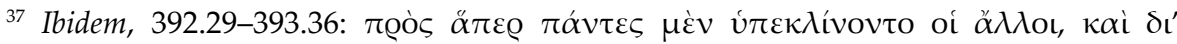

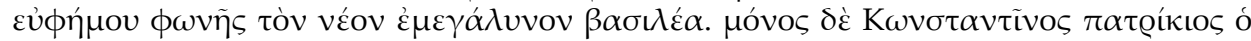

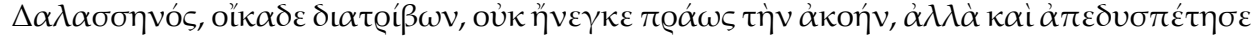

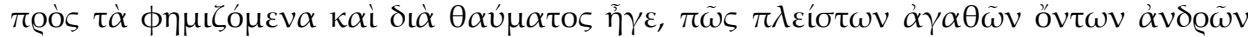

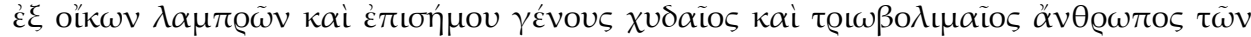

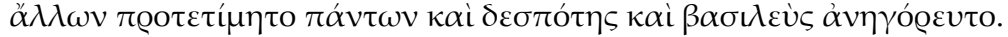


nie sposobu, w jaki doszedł do władzy, lecz jego niskiego pochodzenia, które a priori dyskwalifikowało go jako kandydata do tronu ${ }^{38}$. Powyższy ustęp wskazuje również, że Skylitzes wykorzystał tu źródło nie tylko o wyraźnej proweniencji arystokratycznej, lecz także ściśle związane $z$ Dalassenem. Z jednej strony stawia go w centrum wydarzeń, na co wskazuje podkreślenie, że był jedyną osobą która źle przyjęła wybór Michała na cesarza, a z drugiej ukazuje wydarzenia z innej niż Konstantynopol perspektywy. Dalassen wyraził oburzenie przebywając w swej posiadłości w temie Armeniakon i stamtąd dotarła do stolicy wieść o jego reakcji, która wywołała wielkie zaniepokojenie $\mathrm{u}$ Jana Orfanotrofosa ${ }^{39}$.

Wiele detali zawierają również opisy sprowadzenia Dalassena do stolicy i przyjęcia go przez cesarza: relacja o dwóch poselstwach, przysięga na święte relikwie, nadanie rangi anthypatosa, przydzielenie kwatery w dzielnicy ta Kyrou. Zonaras również relacjonuje to wydarzenie, lecz jego przekaz jest mniej szczegółowy, nie przytacza słów Dalassena ani faktu, że jako jedyny sprzeciwił się wyborowi nowego cesarza. Ogólnikowo przedstawił również sposób, w jaki udało się Orfanotrofosowi przekonać Dalassena do przybycia do stolicy. Nie precyzuje też godności, którą otrzymał, ani miejsca, gdzie go zakwaterowano ${ }^{40}$. Podobne rozbieżności w liczbie szczegółów występują w przekazie dotyczącym buntu mieszkańców Antiochii. Zonaras nie przytacza imienia zamordowanego poborcy podatkowego (Salibasa), nie wspomina również o Elpidiosie, jednym z jedenastu arystokratów antiocheńskich uprowadzonych do Konstantynopola ${ }^{41}$.

W dalszych ustępach Zarysu historii Skylitzes podkreśla obsesję, jaką miał na punkcie Dalassena brat cesarza, który nie reagował na problemy spadające na państwo (Aleppo zerwało traktat pokojowy, utracona została Myra, wschodnie pogranicze zaatakował król Gruzji Bagrat IV, Pieczyngowie najechali prowincje bułgarskie, a berberyjscy piraci złupili Cyklady), gdyż jedyną jego troską było utrzymanie kontroli nad niezadowolonym arystokratą. W ustępie tym powtarza się również wątek niskiego pochodzenia oprawców Dalassena. Jan Orfanotrofos przeniósł arystokratę z Platei do strzeżonej wieży, gdzie pilnowali go nisko urodzeni strażnicy ${ }^{42}$. Warto w tym miejscu powrócić do przekazu Zonarasa, który chociaż jest

${ }^{38}$ Interesujące uwagi $\mathrm{w}$ tej kwestii poczynił A. Lounghis, The Byzantine historians on politics and people from 1042 to 1081, „Byzantion” 2002, t. 72, nr 2, s. 386-387, którego zdaniem Dalassenowi chodziło o Paflagonię jako o miejsce, gdzie cesarzowa mogła znaleźć lepszego kandydata na męża i cesarza niż Michał.

${ }^{39}$ Skylitzes, Synopsis, 393.36-37

${ }^{40}$ Zonaras, Epitomae, 588.3-12.

${ }^{41}$ Ibidem, 588.3-589.4.

${ }^{42}$ Skylitzes, Synopsis, 396.37-397.49. 
mniej szczegółowy niż Skylitzes, to jednak jego relacja jest podobna. Sugeruje to, że korzystał z tego samego źródła, z jego innej kompilacji lub bezpośrednio z Zarysu historii. Znamienne, że Zonaras wspomina o zagrożeniach, jakie spadły na cesarstwo, lecz nie przytacza nieprzychylnej Janowi Orfanotrofosowi informacji Skylitzesa o zaniedbywaniu tych spraw z powodu obsesji dotyczącej Dalassena ${ }^{43}$. Wydaje się zatem, że chociaż obaj historycy skorzystali ze zbliżonego źródła lub Zonaras z kroniki Skylitzesa (co wydaje się bardziej prawdopodobne), to jednak przekaz Skylitzesa $\mathrm{w}$ rozdziale poświęconym panowaniu Michała IV jest znacznie bardziej przychylny Dalassenowi. W konsekwencji Skylitzes skrupulatnie odnotował wiele detali na jego temat, podczas gdy Zonaras przejawiał znacznie mniejsze zainteresowanie arystokratą. $Z$ tego też powodu nie informuje o skazaniu na wygnanie z inicjatywy Orfanotrofosa braci Konstantyna Dalassena, Teofylakta i Romana, oraz innych członków rodziny. Nie wspomina też o krytyce Orfanotrofosa za wprowadzenie niesprawiedliwych i uciążliwych podatków, w tym aerikonu ${ }^{44}$.

Kolejnych argumentów dostarczają informacje pominięte przez Skylitzesa, a obecne w innych źródłach. Autor Zarysu historii pomimo wyraźnego zainteresowania Dalassenem przemilczał fakt, że Michał V wypuścił go na wolność ${ }^{45}$ oraz, co istotniejsze, informację o ponownym rozważeniu jego kandydatury na cesarza. Kwestię amnestii pominął zapewne ze względu na jej upokarzające dla Dalassena warunki, o których napisał Psellos (cesarz zmusił go do wstąpienia do klasztoru). Z tego samego powodu nie wspomina niepomyślnej dla niego rozmowy z cesarzową Zoe, gdy ta szukała nowego kandydata na męża i cesarza po upadku Paflagończyków. Psellos informuje, że cesarzowa Zoe obrała sobie Dalassena na nowego kandydata na męża i sprowadziła go w tym celu do pałacu pod pretekstem rozważenia jakiejś innej sprawy. Okazał się jednak człowiekiem apodyktycznym, nieustępliwym i ogólnie o trudnym charakterze i sam, zdaniem Psellosa, zniweczył swe nadzieje ${ }^{46}$. W podobnym tonie wypowiada się Zonaras ${ }^{47}$. Nic więc dziwnego, że Skylitzes nie przytoczył tych informacji, można z całą dozą pewności założyć, że nie zawierało ich jego źródło przychylne Dalassenowi. Gdyby Skylitzes posiadał relację

${ }^{43}$ Zonaras, Epitomae, 589.11-590.12.

${ }^{44}$ Skylitzes, Synopsis, 404.50-59, warto zaznaczyć, że aerikon był podatkiem bardzo starym, wspomina o nim już Prokopiusz z Cezarei, Historia sekretna, red. A. Konarek, Warszawa 1969, 21, 1; wydaje się zatem, że Orfanotrofos po prostu podniósł jego wysokość, N. Oikonomides, Fiscalité et exemption fiscale à Byzances, Athènes 1996, s. 81.

${ }^{45}$ Attaleiates, Historia, red. I. Bekker, CSHB, Bonn 1853, 11.15-18.

${ }^{46}$ Psellos, Cronografia, VI, 12.

${ }^{47}$ Zonaras, Epitomae, 614. 9-12. 
ukazującą te wydarzenia w sposób sprzyjający Dalassenowi, zapewne by ją wykorzystał.

Z analizy porównawczej relacji Skylitzesa oraz innych źródeł wynika zatem, że Skylitzes przejawiał szczególne zainteresowanie Konstantynem Dalassenem i nie licząc jednej chłodnej wzmianki powstałej pod wpływem źródła przychylnego Romanowi III Argyrosowi, był zdecydowanie pozytywnie do niego ustosunkowany. Wydaje się, że ukazanie w korzystnym świetle Konstantyna Dalassena, jego praw do tronu cesarskiego oraz wynikających z tego prześladowań było związane z funkcją propagandowa jaką w zamyśle Skylitzesa pełniła ta postać w owej narracji. Kluczem do interpretacji przekazu Zarysu historii są związki Dalassenów z cesarzem Aleksym I Komnenem, za którego panowania Skylitzes spisał Zarys historii ${ }^{48}$. Osobą łączącą Komnena z Dalassenami jest oczywiście jego matka Anna Dalassena.

Ważna rola, jaką pełniły na dworze Aleksego I Komnena Anna Dalassena, cesarzowa Irena Dukaina czy była cesarzowa Maria z Alanii, wynikała $\mathrm{z}$ ugruntowanej w XI w., ale i zakorzenionej $\mathrm{w}$ dawnej tradycji, żeńskiej formy legitymizacji władzy ${ }^{49}$. Jedenastowieczny trend zapoczątkowała śmierć w 1028 r. Konstantyna VIII, ostatniego męskiego przedstawiciela dynastii macedońskiej. Władcy, którzy wstąpili po nim na tron, przez niemal trzy następne dekady legitymizowali swe panowanie dzięki związkom z jedną z córek cesarza, Zoe lub Teodorą ${ }^{50}$. Poprzez małżeństwo z Zoe władzę sprawowali Roman III Argyros, Michał IV Paflagończyk oraz Konstantyn IX Monomach, natomiast Michał V Kalafates uzyskał władzę jako adoptowany syn cesarzowej ${ }^{51}$. Z kolei umierająca Teodora wyznaczyła na swego następcę Michała VI Starego. Jej śmierć ściągnęła jednak na państwo poważny kryzys, który zakończył się rebelią arystokracji pod wodzą Izaaka I Komnena i obaleniem Michała VI. Nie był to jednak koniec tradycji ukształtowanej po 1028 r. Eudokia Makrembolitissa, wdowa po Konstantynie X Dukasie, usankcjonowała poprzez małżeństwo panowanie Romana IV Diogenesa jako protektora małoletniego Michała VII

\footnotetext{
${ }^{48}$ C. Holmes, Basil II, s. 85-86.
}

${ }^{49}$ B. Hill, Imperial Women and the Ideology of Womanhood in the Eleventh and Twelfth Centuries, [w:] Women, Men, and Eunuchs: Gender in Byzantium, red. L. James, Routledge 1997, s. 79.

${ }^{50}$ L. Garland, Byzantine Empresses: Women and Power in Byzantium AD 527-1204, Routledge 1999, s. 157.

${ }^{51}$ D. C. Smythe, Behind the Mask: Empresses and Empire in Middle Byzantium, [w:] Queens and Queenship in Medieval Europe, red. A. Duggan, Woodbridge 1997, s. 145, uważa nawet, że na wczesny XI w. należy patrzeć przede wszystkim jako na panowanie Zoe, a nie jej mężów i adoptowanego syna; na temat adopcji Michała V przez Zoe zob. R. Macrides, Kinship by Arrangement: The Case of Adoption, DOP 1990, t. 44, s. 117. 
Dukasa. Z kolei żona Michała VIII, Maria z Alanii, wyszła za uzurpatora Nicefora III Botaniatę, gdy ten obalił jej męża. Gruzińska księżniczka chciała zapewnić sukcesję dla syna Konstantyna. Botaniata uczynił jednak swym następcą Nicefora Synadenosa, pozbawiając Konstantyna jego praw $^{52}$. Postępowanie Botaniaty okazało się nierozważne i skończyło się jego obaleniem przez sojusz Komnenów i Dukasów. Wydatną rolę w zawarciu sojuszu odegrała Maria z Alanii, usynowiając Aleksego Komnena i zobowiązując go do uznania praw Konstantyna ${ }^{53}$.

Również Anna Dalassena pełniła istotną rolę legitymizującą panowanie Aleksego I. „Matka Komnenów” była symbolicznym łącznikiem panowania cesarza z dawną epoką. Obok Bazylego II była osobą która walnie przyczyniła się do rozkwitu rodziny Komnenów ${ }^{54}$. Dalekowzroczna i roztropna polityka matrymonialna Dalasseny doprowadziła do powstania sieci sojuszy, której nikt nie mógł się przeciwstawićs ${ }^{55}$. Nie mógł tego uczynić ani Nicefor III Botaniata, ani kolejni pretendenci za panowania Aleksego $^{56}$. Podczas gdy cesarz zajęty był nieustającymi wojnami z Normanami, Pieczyngami i Turkami, jego matka sprawowała faktyczną kontrolę nad cywilnym zarządem państwa. Szerokie prerogatywy Dalasseny zostały dokładnie zdefiniowane i potwierdzone w złotej bulli cesarskiej, czyniąc z niej faktyczną panią cesarstwa pod nieobecność syna ${ }^{57}$. Warto w tym kontekście zwrócić uwagę na ówczesną pozycję polityczną Jana Skylitzesa. Gdy Anna sprawowała faktyczną kontrolę nad państwem, autor Zarysu historii piastował szereg ważnych funkcji administracyjnych

${ }^{52}$ L. Garland, Byzantine Empresses, s. 173, 182.

${ }^{53}$ Ibidem, s. 173, 182-183.

${ }^{54}$ J. Dudek, Obraz przeszłości rodu Komnenów według Materiałów historycznych Nicefora Byrenniosa i Aleksjady Porfirogenetki Anny, [w:] Cognitioni gestorum. Studia z dziejów średniowiecza dedykowane Profesorowi Jerzemu Strzelczykowi, red. D. A. Sikorski, A. M. Wyrwa, Warszawa 2006, s. 287-288.

${ }^{55}$ B. Hill, Alexios I Komnenos and the Imperial Women, [w:] Alexios I Komnenos. Papers on the Second Belfast Byzantine International Colloquium, 14-16 April 1989, red. M. Mullet, D. C. Smythe, Belfast 1996, s. 39.

${ }^{56}$ Wykaz buntowników przedstawił, J. C. Cheynet, Pouvoir et contestations à Byzance (963-1210), Paris 1990, s. 91-103; za najgroźniejszą dla Aleksego I należy uznać konspirację Nicefora Diogenesa, P. Frankopan, Challenges to Imperial Authority in the Reign of Alexios I Komnenos: the Conspiracy of Nikephoros Diogenes, „ByzSlav” 2006, t. 64, s. 259, badacz łączy również ze spiskiem Diogenesa powstania na Krecie i Cyprze, idem, Challenges to Imperial Authority in Byzantium: Revolts on Crete and Cyprus at the end of the 11th century, "Byzantion” 2004 , t. 74, s. 400-401.

${ }^{57}$ Treść bulli przytacza Anna Komnena, Alexias, red. A. Kambylis, D. R. Reinsch, CFHB, 40, Berlin-New York 2001, III, 6, 4; Dalassena była kompetentnym administratorem, lecz wiele jej decyzji było krytykowanych przez otoczenie, L. Garland, Byzantine Empresses, s. 191. 
i sądowniczych w stolicy ${ }^{58}$. Bez wątpienia Skylitzes jako ważny urzędnik państwowy znał Annę Dalassenę osobiście. Jest również prawdopodobne, że to właśnie matka cesarza dostarczyła Skylitzesowi materiałów dotyczących Konstantyna Dalassena, a być może objęła nawet kronikarza mecenatem ${ }^{59}$.

Zadaniem, jakie postawił sobie Jan Skylitzes przy konstruowaniu narracji dotyczącej Dalassenów, było ukazanie Konstantyna Dalassena jako osoby, która została namaszczona na cesarza przez ostatniego przedstawiciela dynastii macedońskiej, a zatem na prawowitego dziedzica cesarstwa. Chociaż plan Konstantyna VIII nie doszedł do skutku, to jednak już sama tylko wola cesarza dawała Dalassenowi w oczach autora Zarysu historii prawo do tronu cesarskiego. Skylitzes nie przytoczył wprawdzie powodów, którymi kierował się Konstantyn VIII, lecz wyraził je w krytyce Michała IV, którą włożył w usta Dalassena. Słusznie zauważył JeanClaude Cheynet, że wypowiedź Dalassena posiada wspólny mianownik ze słowami Bardaniosa Turka ${ }^{60}$, który planował bunt przeciwko Niceforowi I. Bardanios dowiedział się o mnichu z Filomelionu, który potrafił przepowiadać przyszłość. Usłyszał od niego, że nie zdobędzie władzy cesarskiej, lecz uchwyci ją dwóch spośród jego towarzyszy (przyszły Leon $\mathrm{V}$ i Michał II), a trzeci (Tomasz Słowianin) zostanie proklamowany, lecz nie będzie panował i umrze straszną śmiercią. Bardanios nie uwierzył mnichowi, odpowiadając, że jest niemożliwe, aby jemu, patrycjuszowi i domestykowi o szlachetnym pochodzeniu, nie udało się objąć władzy, a mieli ją zdobyć wyrobnicy niewiadomego pochodzenia ${ }^{61}$. Trudno powiedzieć,

${ }^{58}$ Anna sprawowała władzę w latach 1081-1095, jej ostatnim aktem był rozkaz oślepienia Nicefora Diogenesa, B. Skoulatos, Les personnages byzantins de I'Alexiade: Analyse prosopographique et synthese, Louvain 1980, s. 22; Skylitzes za rządów Aleksego I Komnena sprawował funkcje proedrosa (lata 80.), drungariusza wiglii (1090 r.), eparchy (1090 r.) i kuropalaty (1092 r.), zob. W. Seibt, Ioannes Skylitzes, s. 85; większość z tych godności przestał sprawować przed 1094 r., gdyż na liście uczestników synodu w Blachernach jako eparcha występuje niejaki Michał, a jako drungariusz wiglii Michał Mermentoulos, P. Gauthier, Le Synode des Blachernes (fin 1094) Ètude Prosopographique, RÉB 1971, t. 29, s. 217; zgodnie z jedną z interpolacji do Zarysu historii Michał Mermentoulos był igumenem klasztoru Studios za panowania Konstantyna IX Monomacha, Jan Skylitzes, Synopsis, 434.44.

${ }_{59}$ M. Mullet, Aristocracy and Patronage in the literary circles of Comnenian Constantinople, [w:] Byzantine Aristocracy IX to XIII Centuries, red. M. Angold, B.A.R. 1984, s. 178, badaczka uważa, że Anna Dalassena mogła być patronką kręgu literackiego (kyklos lub theatron) gromadzącego pisarzy i poetów, podobnie jak Anna Komnena, Irena Dukena czy Maria z Alanii. Jednakże, jak przyznaje sama autorka, brak jest jednoznacznych dowodów mogących potwierdzić tę hipotezę; na temat kręgu literackiego zob. P. Marciniak, Greek Drama in the Byzantine Times, Katowice 2006, s. 33-36.

${ }^{60}$ J. C. Cheynet, The Byzantine Aristocracy and its Military Function, Ashgate Variorum Reprints 2006, s. 15-16.

${ }^{61}$ Skylitzes, Synopsis, $10.40-44$. 
czy Skylitzes jest autorem słów Bardaniosa. Epizod ten odnajdujemy też w pierwszej księdze Kontynuacji Teofanesa, jednakże jej autor nie wspomina o takiej reakcji buntownika na słowa mnicha z Filomelionu. Stwierdza jedynie, podobnie jak Skylitzes, że Bardanios początkowo zezłoszczony, wyśmiał te słowa ${ }^{62}$. Skylitzes przedstawia zatem eugeneię jako najważniejszą cechę dobrego cesarza, pomimo że w IX w. i w pierwszej połowie XI w. nie posiadała jeszcze tak dużego znaczenia, jak za rządów Aleksego I Komnena, co odzwierciedlają różnice między przekazem Kontynuacji Teofanesa i Zarysu historii.

Prześladowania Konstantyna Dalassena przez Michała IV i Jana Orfanotrofosa miały być w zamyśle autora Zarysu historii tylko potwierdzeniem praw rodziny Dalassenów. Niechęć Skylitzesa do paflagońskich parweniuszy niewątpliwie wiązała się z faktem, że Komnenowie i znaczna część ich stronnictwa wywodzili się właśnie z Paflagonii ${ }^{63}$. Dalassen jest zatem w Zarysie historii pierwszym wyrazicielem niezadowolenia arystokracji, która doprowadziła do upadku rządów frakcji pałacowej i wysuwanych przez nią cesarzy i osadziła na tronie przedstawiciela rodziny paflagońskiej Izaaka Komnena ${ }^{64}$. Przekaz kroniki Skylitzesa należałoby więc odczytać następująco: rodzina Dalassenów posiadała pełnię praw do tronu cesarskiego, przyznaną jej przez Konstantyna VIII, ostatniego męskiego potomka dynastii macedońskiej. Udział w tym dziedzictwie posiadał również Aleksy I Komnen, a otrzymał je od matki Anny Dalasseny. Zatem zdaniem Komnenów i ich stronników prawa Aleksego I do tronu cesarskiego pochodziły od aktów dwóch ostatnich cesarzy dynastii macedońskiej. Komnenowie postawili na tego typu retorykę ze względu na fakt, że nie mogli poszczycić się wspaniałą genealogia jak wiele innych rodzin arystokratycznych ${ }^{65}$. Wprawdzie w kulturze bizantyńskiej nie było niczym niezwykłym tworzenie mitycznej genealogii wielkich rodzin arystokratycznych i dynastii cesarskich, jak chociażby w przypadku Macedończyków, których protoplasta Bazyli I miał być potomkiem partyjskich

${ }^{62}$ Theophanes Continuatus, red. I. Bekker, CSHB, Bonn 1838, 8.8-12.

${ }^{63}$ A. Lounghis, The Byzantine historians, s. 392-393, sądzi nawet, że Skylitzes mówiąc o buncie arystokratów ze wschodu ( $\tilde{\omega} \omega \varsigma)$ pod wodzą Komnenów i Dukasów, nie miał na myśli „wschodu” (Anatolii), lecz Paflagonię.

${ }^{64}$ Tym wydarzeniem kończy się Zarys historii $\mathrm{w}$ jego podstawowej redakcji, istnieje

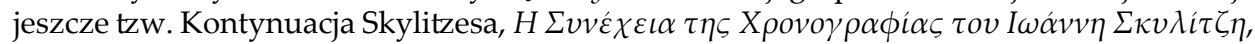
red. E. T. Tsolakis, Thessaloniki 1968, jednakże jej autorstwo jest przedmiotem sporu.

${ }^{65}$ Komnenowie to stosunkowo młoda rodzina, której najstarszym znanym przedsta-

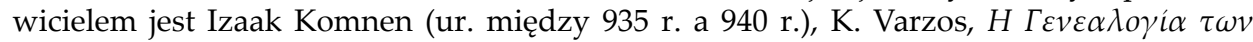
Ko $\mu v \eta v \omega v$, 1, Thessaloniki 1984, s. 37-38; fakt przyjęcia przez Manuela, syna Izaaka, nazwiska żony z rodziny Erotikosów świadczy o początkowym niewielkim znaczeniu Komnenów. 
i armeńskich Arsakidów ${ }^{66}$. Początki rodziny Dukasów miały sięgać Konstantyna Wielkiego ${ }^{67}$, a Nicefor III Botaniata poprzez pokrewieństwo z Fokasami wywodził swój rodowód od rzymskich Fabiuszy ${ }^{68}$. Historiografia panowania Aleksego I Komnena poszła w innym kierunku, nie stworzyła mitycznej genealogii rodziny, lecz postanowiła wykazać związek między Komnenami i dynastią macedońską, a w szczególności z już wtedy legendarnym cesarzem Bazylim II Bułgarobójca ${ }^{69}$. Rodowód tego typu był dla mieszkańców cesarstwa, u których żywa była pamięć wielkiego cesarza, bardziej wiarygodny i realny ${ }^{70}$.

Zatem Aleksy Komnen odziedziczył prawa do tronu cesarskiego patrylinearnie, dzięki wychowaniu jego ojca przez Bazylego II, a także matrylinearnie, dzięki dziedzictwu Dalassenów. Warto również w tym kontekście powrócić do kwestii pominięcia przez Skylitzesa spotkania Konstantyna Dalassena z cesarzową Zoe, ostatnią przedstawicielką dynastii macedońskiej. Gdyby Skylitzes przytoczył ten epizod, podałby w wątpliwość pretensje Komnenów i Dalassenów do macedońskiego dziedzictwa. Przedstawienie przez Jana Skylitzesa losów Konstantyna Dalassena odpowiadało z jednej strony ówczesnym gustom arystokratycznych odbiorców historiografii, z drugiej zaś potrzebom legitymizacji władzy nowego cesarza. Dziesięciolecia kryzysów dynastycznych i wojen domowych stworzyły potrzebę wykreowania nowego wizerunku władcy, odpowiadającego gustom arystokracji. Oprócz tego Aleksy I Komnen musiał w jakiś sposób uzasadnić swoje prawo do tronu cesarskiego. Komnenowie, jako dynastia o rodowodzie arystokratycznym, musieli zjednać i przekonać do siebie resztę arystokracji, a jednocześnie wykazać swoją wyjątkowość, wyróżniającą ich na tle własnej grupy społecznej. Właśnie w tym celu Nicefor Bryennios i Jan Skylitzes wykreowali związki łączące Komnenów i Dalassenów z cesarzami Bazylim II i Konstantynem VIII.

${ }^{66}$ Rodowód Bazylego przedstawia w ten sposób Józef Genezjusz, Iosephi Genesii regum libri quattuor, CFHB, 19, Berlin 1978, 76.61-62; powtórzył go później jego wnuk Konstantyn VII, Chronographie que Theophanis continuati nomine fertur liber quo Vita Basilii Imperatoris amplecitur, red. I. Sevcenko, CFHB, 42, Berlin 2011, 12.25; wedle relacji Niketasa Dawida Paflagończyka, Vita S. Ignatii archiepiscopi Constantinopolitani, red. J. P. Migne, Patrologia Graeca, 105, Paris 1862, 565-568, autorem legendy o partyjskim rodowodzie Bazylego był Focjusz, usunięty z tronu patriarszego chciał w ten sposób odzyskać przychylność cesarza.

${ }^{67}$ Nicefor Bryennios, Nicephori Bryenni Commentarii, red. A. Meineke, CSHB, Bonn 1836, 13.5-13.

${ }^{68}$ Attaleiates, Historia, 218.9-12.

${ }^{69}$ P. Stephenson, The Legend of Basil the Bulgar-Slayer, Cambridge 2003, s. 86, wiąże wzrost popularności Bazylego II z odrodzeniem się wizerunku cesarza-żołnierza w epoce Komnenów.

${ }^{70}$ J. Dudek, op. cit., s. 286. 


\section{BIBLIOGRAFIA:}

Alexander J. P., Secular biography at Byzantium, „Speculum” 1940, t. 15, nr 2, s. 194-209.

B. Hill, Alexios I Komnenos and the Imperial Women, [w:] Alexios I Komnenos. Papers on the Second Belfast Byzantine International Colloquium, 14-16 April 1989, red. M. Mullet, D. C. Smythe, Belfast 1996, s. 37-54.

Beck H. G., Die hochsprachliche profane Literatur der Byzantiner, München 1978.

Biały K., The Authorship of the Lost Source of John Skylitzes' Synopsis Historion in the Chapter about the Reign of Michael IV, „Eos” 2014, t. 101, nr 2, s. 275-284.

Bonarek J., Konstantyn Dalassenos - spadkobierca rzymskich cnót, [w:] Człowiek w antycznym świecie, red. S. Sprawski, Kraków 2012, s. 397-408.

Catalogue of Byzantine Seals at Dumbarton Oaks and in the Fogg Museum of Art, 5, red. E. McGeer, J. Nesbitt, N. Oikonomides, Washington 2005.

Cheynet J. C., Pouvoir et contestations à Byzance (963-1210), Paris 1990.

Cheynet J. C., The Byzantine Aristocracy and its Military Function, Ashgate Variorum Reprints 2006.

Cheynet J. C., Vannier J. F., Études prosopographiques, Paris 1986.

Dubarle A. M., L'homélie de Grégoire le Référendaire pour la réception de l'image d'Édesse, „Revue des Études Byzantines" 1997, t. 55, s. 5-51.

Dudek J., Obraz przeszłości rodu Komnenów według Materiatów historycznych Nicefora Byrenniosa i Aleksjady Porfirogenetki Anny, [w:] Cognitioni gestorum. Studia z dziejów średniowiecza dedykowane Profesorowi Jerzemu Strzelczykowi, red. D. A. Sikorski, A. M. Wyrwa, Warszawa 2006, s. 277-289.

Frankopan P., Challenges to Imperial Authority in Byzantium: Revolts on Crete and Cyprus at the end of the 11th century, "Byzantion” 2004, t. 74, s. 382-402.

Frankopan P., Challenges to Imperial Authority in the Reign of Alexios I Komnenos: the Conspiracy of Nikephoros Diogenes, „Byzantinoslavica” 2006, t. 64, s. 257-273.

Garland L., Byzantine Empresses: Women and Power in Byzantium AD 527-1204, Routledge 1999.

Gauthier P., Le Synode des Blachernes (fin 1094) Ètude Prosopographique, „Revue des Études Byzantines", 1971, t. 29, s. 213-284.

Hill B, Imperial Women and the Ideology of Womanhood in the Eleventh and Twelfth Centuries, [w:] Women, Men, and Eunuchs: Gender in Byzantium, red. L. James, Routledge 1997, s. 76-99.

Hirsch F., Byzantinische Studies, Leipzig 1876.

Holmes C., Basil II and the Governance of Empire (976-1025), Oxford 2005.

Janin R., Constantinople byzantin. Développement urbain et répertoire topographique, Paris 1964.

Jenkins R. J. H., The Classical Background of the Scriptores Post Theophanem, „Dumbarton Oaks Papers" 1954, t. 8, s. 13-30.

Kazhdan A., The History of Byzantine Literature (800-1000), Athens 2006.

Konstantynopol - nowy Rzym: miasto i ludzie w okresie wczesnobizantyńskim, red. M. J. Leszka, Warszawa 2011.

Krumbacher K, Geschichte der byzantinischen Litteratur von Justinian bis zum Ende des oströmischen Reiches, 527-1453, München 1891.

Laiou A. E., Imperial Marriages and Their Critics in the Eleventh Century: The Case of Skylitzes, „Dumbarton Oaks Papers” 1992, t. 46, s. 165-176.

Ljubarskij J. N., Man in Byzantine Historiography from John Malalas to Michael Psellos, „Dumbarton Oaks Papers" 1992, t. 46, s. 177-186. 
Lounghis A, The Byzantine historians on politics and people from 1042 to 1081, „Byzantion” 2002, t. 72, nr 2, s. 381-403.

Macrides R., Kinship by Arrangement: The Case of Adoption, „Dumbarton Oaks Papers” 1990, t. 44, s. 109-118.

Marciniak P., Greek Drama in the Byzantine Times, Katowice 2006.

Markopoulos A., From narrative historiography to historical biography. New trends in Byzantine historical writing in the 10th-11th centuries, "Byzantinische Zeitschrift" 2009, t. 102, nr 2, s. 696-715.

Mullet M., Aristocracy and Patronage in the literary circles of Comnenian Constantinople, [w:] Byzantine Aristocracy IX to XIII Centuries, red. M. Angold, B.A.R. 1984, s. 173-201.

N. Oikonomides, Fiscalité et exemption fiscale à Byzances, Athènes 1996.

Oikonomides N, Les Listes de Préséance Byzantines Des IXe et Xe Siècles, Paris 1972.

Polemis D. I., Some cases of erroneous identification in the chronicle of Skylitzes, „Byzantinoslavica" 1965 , t. 26, s. 74-81.

Polemis D. I., The Doukai: a Contribution to the Byzantine Prosopography, London 1968.

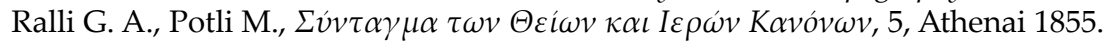

Seibt W., Johannes Skylitzes: Zur Person des Chronisten, "Jahrbuch der Österreichischen Byzantinistik" 1976, t. 25, s. 81-85.

Shepard J., A suspected source of Scylitzes' Synopsis Historion: the great Catacalon Cecaumenus, „Byzantine and Modern Greek Studies” 1992, t. 16, s. 171-181.

Shepard J., Byzantium's Last Sicilian Expedition: Skylitzes' Testimony, „Rivista Studi Bizantini e Noellenici" 1977-1979, t. 14-16, s. 145-159.

Skoulatos B., Les personnages byzantins de I'Alexiade: Analyse prosopographique et synthese, Louvain 1980.

Smythe D. C., Behind the Mask: Empresses and Empire in Middle Byzantium, [w:] Queens and Queenship in Medieval Europe, red. A. Duggan, Woodbridge 1997, s. 141-172.

Stephenson P., The Legend of Basil the Bulgar-Slayer, Cambridge 2003.

Treadgold W., The Middle Byzantine Historians, Palgrave Macmillan 2013.

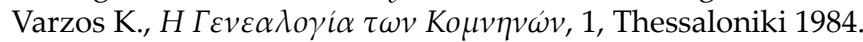

\section{ABSTRACT:}

John Skylitzes, author of the Synopsis Historion was a chronicler who paid special attention to the genealogy of the great aristocratic families and their particular figures. One such person was Constantine Dalassenos. Historian narrated his deeds in a special manner and differs from other contemporary narratives. Analysis of the source material indicates that Skylitzes used special source associated with Dalassenos which is now lost. The fate of Dalassenos was especially interesting to Skylitzes who was an important figure at the court of emperor Alexios I Komnenos and his mother Anna Dalassene. Historian presented Dalassenos' deeds in favourable light: showed him as the original successor of Constantine VIII and as a victim of repressions on part of the low-born Paphlagonians. Skylitzes aim was to highlights links of Dalassenoi with the Macedonian Dynasty and thus strengthen the ideological foundation of Alexios I Komnenos' reign.

Key words: John Skylitzes, Synopsis Historion, Constantine Dalassenos, Anna Dalassene, Alexios I Komnenos, Byzantium. 
NOTA O AUTORZE:

Kamil Biały (jkl20kb@gmail.com) - doktorant w Zakładzie Historii Starożytnej Instytutu Historii i Stosunków Międzynarodowych USz. W swych zainteresowaniach badawczych skupia się na historiografii bizantyńskiej XI wieku oraz recepcji antyku w Bizancjum. Przygotowuje rozprawę doktorską pt. Księgi seweriańskie Historii rzymskiej Kasjusza Diona $i$ ich bizantyńscy epitomatorzy oraz pierwszy polski przekład ksiąg LXXIII-LXXX Historii rzymskiej Kasjusza Diona. 